\title{
Development Perspectives of Bio-Tech Entrepreneurship: The Case of Slovenia
}

\author{
Jaka Vadnjal, Jurij Bernik \\ GEA College of Entrepreneurship, Piran, Slovenia \\ Janez Bernik \\ Independent Consultant, Škofja Loka, Slovenia
}

\begin{abstract}
The development perspectives of the bio-tech entrepreneurship in Slovenia are examined in the paper. The main research question is to examine the conditions for fundaments of wider expansion of this particular industry in Slovenia. Due to a small extent of the industry a qualitative research methodological approach seemed appropriate. Eight companies were interviewed with the objective to reveal the main characteristics of the entrepreneurial ventures established on the basis of science and research driven ambitions of founders who managed to encompass their personal and professional development trails with entrepreneurial paths. There are several peculiarities found in this particular qualitative research which goes along with the literature survey. On the other side, there are some characteristics which may not be regarded as usual in the field of bio-tech entrepreneurship: majority of companies are not spin-offs in are not based on public-funded research, they do not rely on venture capital and seem not to have a very distinguished business model. Half of companies are located in incubators or tech-parks. Participants in the study share similar opinion regarding the support policy of the government. On the other hand, majority of entrepreneurs come from public research institutions not exactly being entrepreneurial from the viewpoint of being profitable but rather in a way, that there is a belief that in private companies they may generally have more flexibility and broader financing opportunities. The understanding of importance of marketing, building on social capital and risk-awareness still seem to be neglected factors among bio-tech entrepreneurs. Still, high level of reliance on public finance, mostly on different EU-sponsored programs can be recognized from the opinions of study participants.
\end{abstract}

Keywords: bio-technology, entrepreneurship, R\&D, science-driven industry, financing

\section{Introduction}

Being a pure science in the beginning (DNA was discovered in 1953 and was recognized as a key genetic material with its basic function of transfer genetic code onto the next generation of living and became a new milestone in understanding lives from bacteria, plants, animals and finally human beings), first commercial

Jaka Vadnjal, Ph.D., Chair of Small Enterprises Economics, GEA College of Entrepreneurship.

Jurij Bernik, M.Sc., Chair of management, GEA College of Entrepreneurship.

Janez Bernik, B.Sc., Independent Consultant.

Correspondence concerning this article should be addressed to Jaka Vadnjal, GEA College of Entrepreneurship, Dunajska 156, SI-1000 Ljubljana, Slovenia. E-mail: jaka.vadnjal@gea-college.si. 
applications were not developed very soon since the first biotech company Genetech Inc. was established in California only in 1976 (Robbins Roth, 2001). Today, the commercialization of the biotechnological inventions and discoveries is known as biotech industry while new ventures in the field are defined as biotech entrepreneurship (Baum, Calabrese, \& Silverman, 2000). On the break of the centuries, the number of biotech companies over the world was estimated to be around 5,000 (Audretsch, 2001) while this number has been tremendously increasing (Becker, 2004).

Biotechnology seems appropriate to research science-based entrepreneurship since during the last two decades there has been an upsurge of new firms (Zucker, Darby, \& Brewer, 1998). In the case of Slovenia, the number of creation of biotech firms is also increasing, from virtually nothing a decade ago, to more than 20 nowadays. There can be no doubt that those new firms are knowledge based since biotechnology is widely acknowledged as a science-based and even a science-driven sector (Cohen, Nelson, \& Walsh, 2002). Another challenging feature of biotech research is that new firms are usually pure cases of entrepreneurship, in the meaning that they are new technology-based firms. Firms are built upon the use of a new technology or the development and production of a new product. However, the problem of knowing whether or not the creation of a new firm can really be considered as a case of entrepreneurship is ignored in this case (Metcalfe, 2004).

Although US seem to play the leading role in the field, there is also an increasing activity in Europe, mainly in UK but also in Germany and France while other countries are far behind (Cooke, 2001). Moreover, while technology part of the biotech had been predominantly studied, the attraction of the researchers is more and more often dragged to entrepreneurial part of the biotechnology (Fuchs, 2001) which causes the emergences of this intriguing field also in other parts of the world including emerging and smaller, also transition economies (Stuart \& Ding, 2006). Although industrial dynamics and technology trends in biotech are defined globally, the national institutional rules, tradition and politics do have a large impact in the activity of biotech companies in the social and economic environment at the national level (Nilsson, 2001) and urge for positive trends such as increasing numbers of science graduates worldwide, accelerating pace of scientific advancement, dominating role of globalisation enabling greater collaboration, democratising forces of the internet, and the relentless competitive pressure to innovate. As such, policy agendas should focus on increasing factor conditions to enhance start-up formation, alliances, and skilled employment, rather than attempt to select specific winners and losers among specific sub-sectors or individual firms (Ahn \& Meeks, 2007). The particularities of the Slovene environment influencing the development of biotech entrepreneurship are therefore the main motivation for writing this paper.

\section{Literature Overview and Research Questions}

There are several pillars in the entrepreneurial process and business modeling that differentiate biotech businesses from other entrepreneurial ventures: (1) The industry is research and science driven; (2) There is a predominant role of patenting possibility in order to secure awards for risk taking; (3) Entrepreneurial abilities have to go beyond traditional innovation and risk paradigms to capability of managing heterogeneous networks (clusters); (4) The importance of public science; and (5) Availability of venture capital (Wolff, 2001).

Biotech start-ups are usually founded by a small number of people who personally assume the direction of the project. Motivations of those founders, which are often not only profit oriented, and the recourse to credit to launch the business are also in line with Schumpeter's early view on entrepreneurship and entrepreneurs. 
Founders are often individuals endowed with a strong experience either scientific or managerial (Radosevic, 2002).

Yet, this view of entrepreneurship ignores interdependences between the multiple actors of innovation. It comes from a deep misunderstanding of entrepreneurship in biotech, which is mainly a collective process that relies on the assembling of competences distributed across a large number of agents. The entrepreneur is not a single agent but belongs to a network and has to interact with other members to succeed in his enterprise. In short, the locus of innovation has shifted from individual organizations to networks (Baum et al., 2000).

Yet, if networks are the central drivers of innovation it does not mean that individual entrepreneurs play no role. They still need to develop specific competences, at least to ensure the creation of their network. In this sense, competences such as the ability to bridge different culture, open-mindedness, etc., may become central. The entrepreneur must have the ability to set-up agreements among all interested parties (such as the inventor of the process, the partners, the capitalists, the suppliers, the distributors), to enlist cooperation of official agents, to put together adequate staff, etc.. This ability to bridge heterogeneous networks and persons may become far more important for entrepreneurs in biotech than scientific or managerial abilities (Orsenigo, 2001). Thus, the main case in a successfully started bio-tech venture may be the ability of individuals and entrepreneurial teams to shift from award-winning entrepreneurs to real-life entrepreneurs (Wolf, Michelsen, \& Schwartz, 2010).

One element to be put forward is the role of public research for new biotech start-ups. Many new biotech firms stem from the academic community (are academic spin-offs or at least are mixed structure from the academia and industry) and even for those that are not, it is central to establish strong links and to collaborate with public labs. This central role of public research in the development of the biotech industry was already emphasized by Zucker et al. (1998), who showed that in the US during the early days of the biotech industry, there was a very positive correlation among the local presence of a university and the development of biotech start-ups. However, this huge reliance on public research sector to play a crucial role in the biotech start-ups seems to be more European and US matter, while in Japan a lot of bio-tech start-ups are intrapreneurial ventures mostly from pharmaceutical companies (Jolivet, Lanciano-Morandat, Nohara, \& Pardo, 2009).

Also the cooperation with public research organizations is reported to be of high importance for biotech start-ups. Collaboration with universities is central to increase firms' reputation and to achieve scientific credibility. Here, collaborations essentially aim at increasing the firms' attractiveness for financers or potential partners. Star scientists among others, by their ability to bridge different communities, ensure to the entrepreneur the scientific visibility necessary in order to collect funds and to develop collaborations (Zucker \& Darby, 1999). Despite an increase in life science technology commercialization and venture creation, graduate schools have largely failed to provide adequate opportunities for students to acquire knowledge and experience in bio-entrepreneurship. Postdoctoral trainees and graduate students have recognized this educational gap, as well as a role in complementing university run bio-entrepreneurship programs, and formed student organizations that foster bio-entrepreneurship education (Brown \& Kant, 2009). On the other hand, advanced degrees that combine master's in business with master's in biotechnology are popping up at several universities. The programs are targeted to students who will bridge the gap between scientist and managers in biotech companies (Waltz, 2006).

Many empirical studies are suggesting that the most important asset for entrepreneurship in biotech is patent and that without patents there would have been few investments in biotech. The prominent role of patents in 
biotech goes back to the origin of the sector. There is indeed a strong correlation between the birth of the industry and important changes in patent laws, which suggests that patents played a central role in the birth and development of the biotech industry (Hemphill, 2003). It is possible that without the patent system the biotechnology revolution would not have reached the dimension it has nowadays.

In life sciences, and contrary to most other sectors, it has indeed been shown that patents are highly important to appropriate the returns of an innovation and to enhance incentives (Combs \& Metcalfe, 2002). Firms acting specifically in biotechnologies are usually small and young companies faced with high competitive pressures and thus they intensively rely on patents because they do not have any other tangible asset. Biotechnology companies may apply for patents not only in order to exclude rival firms but also to facilitate collaborations and interactions. Without patents those firms would have no guarantee to offer to potential partners and to financing institutions (Bureth, Levy, Pénin, \& Wolff, 2005).

Biotechnology is a money-consuming business. Biopharmaceuticals, for example, demand more than $\$ 100$ million for R\&D expenditure and a 12-year development process before they enter the market (DiMasi, Hansen, \& Grabowski, 2003). Other biotechnological products such as genetically engineered plants or platform technologies also demand high $R \& D$ expenditures before generating revenues. For most young bio-ventures, financing these expensive processes depends on the availability of VC capital and development of stock markets. Therefore, the development of the biotechnology industry is substantially influenced by the munificence of the financing environment (Prevezer, 2001). In several countries the present financial crisis seems to begin to trigger a certain drop in biotech activity (Patzelt \& Audertsch, 2008).

\section{Methodology}

Our empirical research was conducted on eight businesses operating in biotechnology industry. The examined businesses are all located in the capital of Slovenia where also the largest university in the country is based with reasonably developed live-science departments. A case study method was used as a qualitative research approach in order to answer the research questions. The sample was defined on the basis of knowledge, information and personal network the authors have of biotechnology-based businesses operating in Slovenia.

There seem to be two reasons for this: one is in the character of the target group which as proposed functions in a specific economic system and second, researching technology-based businesses has become a new approach in the field of academic interest for small business and entrepreneurship thus, even enhancing the common problems with establishing trust between all parties in the research.

The research was conducted in a period from January to September, 2009. Data collection was based on semi-structured personal interviews with the owners of businesses and in two cases accomplished with business partners/co-founders. Interview encompassed seven specific questions for owners. One of the reasons for choosing the particular qualitative research, which is a case study method, is that this appears to be a prevailing methodology in small sample business research worldwide. However, the lack of the data based on biotechnology businesses which would include contact details (i.e., name, phone and address) determined the need for developing a flexible and cost effective methodology which would allow the researchers to identify, reach and communicate with the target population and to adapt the techniques of data collecting to the circumstances found. On the other hand, quantitative approaches would be challenged with conditioning 
sampling methodology and in terms of potential bias.

Three interviews were conducted by teams of two researchers and two were conducted by one researcher. It has been assumed that voice- or video-taping may not be appropriate and would lead the respondents to aversion from revealing all the information and thoughts and may distort other levels of communication. Only hand written minutes were taken and the story was transcribed immediately after the interview. In all cases interviews took place at the premises of the company which should normally enhance the comfort and relaxation of collocutors. The interviews took place at various times of the day, mostly during the working days. It is believed the timing and place of the interview did not anyhow negatively influence on the readiness and openness to reveal data and information.

The following research questions were addresses to entrepreneurs based on the subjective assumptions of the researchers and literature search presented in the previous chapter:

RQ1: How did you get the idea, what was your motive for entrepreneurship? (Becker, 2004);

RQ2: Why did you decide to start a company on the field of biotechnology? (Metcalfe, 2004);

RQ3: What is your entrepreneurial background? (Radosevic, 2002);

RQ4: What would be a popular description of your product/service: what do you develop, produce and sell? (Orsenigo, 2001);

RQ5: What is your business model (suppliers, customers, marketing strategy, business economics and control of costs, break-even point)? (DiMasi et al., 2003);

RQ6: What is your opinion about biotechnological environment, status of biotechnology, possibilities of development in Slovenia and in extended region? (Stuart \& Dieng, 2006);

RQ7: What are your expectations from the support institutions on the field of entrepreneurship (ministries, universities, research institutes, governmental agencies, incubators, technology parks)? (Wolff, 2001).

\section{Results}

\section{Demographics of Study Participants}

Basic demographic data regarding the researched group of company is gathered in Table 1. All the companies are located in the capital of Slovenia, being from four to 20 years old. They employed from three to 15 people at the time of interviews and are managed by founders which six out of eight possess post graduate degrees (two on masters and four on doctoral level) which in a way confirm the paradigm of bio-tech entrepreneurship as a research driven industry.

Table 1

Demographic Data

\begin{tabular}{|l|l|l|l|l|l|l|}
\hline Case & Activity & Location & Age & Education of founders & Founded & Employees \\
\hline C1 & $\begin{array}{l}\text { Laboratory and process } \\
\text { equipment }\end{array}$ & Ljubljana & 49 & B.Sc. in informatics & 1990 & 7 \\
\hline C2 & $\begin{array}{l}\text { Bioelectromagnetics and new } \\
\text { biology }\end{array}$ & Ljubljana & $30-60$ & From high school to Ph.D. & $1990 / 2004$ & 14 \\
\hline C3 & Cell therapy service & Ljubljana TP & n/a & Ph.D. & 1997 & 10 \\
\hline C4 & Personalized genetics & $\begin{array}{l}\text { Dublin, Ireland and } \\
\text { Ljubljana TP }\end{array}$ & 24 & Master degree & 2005 & 10 \\
\hline C5 & Consulting, engineering, R\&D & Ljubljana & 50 & Master degree & $1989 / 1996$ & 5 \\
\hline
\end{tabular}


(Table 1 continued)

\begin{tabular}{|l|l|l|l|l|l|l|}
\hline Case & Activity & Location & Age & Education of founders & Founded & Employees \\
\hline C6 & $\begin{array}{l}\text { Personalized genetics- } \\
\text { nutriogenomics }\end{array}$ & Ljubljana TP, Koper TP & 34 & B.Sc. in economics & 2008 & 5 \\
\hline C7 & Cell therapy_cancer & Ljubljana & 43 & Ph.D. & 2010 & 3 \\
\hline C8 & $\begin{array}{l}\text { Development of molecular and } \\
\text { genomic tools }\end{array}$ & Ljubljana & 35 & Ph.D. & 2001 & 15 \\
\hline
\end{tabular}

Note. * Means “technology park” which is also synonym for incubator, university incubator etc.. Source: Own research $2009-2010$.

\section{Case Studies}

Fourteen Slovenian companies from the fields of biotech, medical and pharmaceutical science, medical and laboratory equipment, were invited to collaborate in the research. Six directors of companies from the field of biotechnology have refused participation in personal interviews from different reasons: either they had no interest or, they reported to be too busy or had other priorities in a given moment. We completed a qualitative research on the sample of eight companies or institutions:

BIA Ltd. was established in 1990 and employed seven highly specialized professionals at the time of interview who perform work on the fields of development and marketing activities. Their main activity is selling products and services on the fields of chromathography, biotechnology, organic synthesis and lab equipment. They develop solutions for tracking and monitoring bioprocesses and simple LIMS (Laboratory Information Management Systems). From BIA, a new spin-off company BIA Separations has been established, which is today a world leading producer of monolithic chromathographic columns based on CIM (Conventive Interaction Media). Their business partners and customers are several companies and research institutions in pharmaceutical in food industry.

Institute Bion Ltd. is a spin-off company from a publicly funded research institute and since 2004 it operates as a private limited company. However, the origins of their activity go back in 1990. Their main focus is the impact and influence of electromagnetic fields on live organisms. Since 2003 they have been intensively researching bio-fields or subtle fields. The institute performs basic and applied research on the field of bio-electromagnetics. They are financed mostly from public tenders, they cooperate with industry and other companies for which they provide specialized research services. Also they perform training and cooperate with universities at diploma, master level and doctoral research.

Educell Ltd. is a company, operating since 1997 and it is the first institution, which gained the status of the institute for tissues and cells from the public agency of the RS for medicine and medical remedies in 2008. The company was established on the basis of the research project started at the publicly funded institute and they currently operate at Ljubljana Technology Park. The venture was backed by a VC fund in late 1990s and was lately acquired by another company. Their provide cell therapy processes intended to cure joint cartilage and bone tissue. They cooperate with clinics in several medical fields: orthopedic, trauma and urology of the university clinical centre Ljubljana which is currently their sole customer. They grow cells in the most modernly equipped laboratories. Their field of work is tissue engineering for very various purposes.

Gene Planet Ltd. was established in 2005 and is registered in Dublin, Ireland, because they believe that support for high-tech companies is much better recognized there. The company was established by several founders and business angels have also contributed to the initial capital. At the time of the interview, it employed 
ten people. The main company's service is personalized genetics. The essence of this service is to draw someone's attention to the individual's genetic predisposition for the disease which can be detected early by frequent preventive examinations and therefore early treated. It is a DNA analysis of individual's saliva and interpretation of results. In this way the company connects high science with life and health of individuals. The service is highly innovative and entirely new in Europe therefore, intensive and extensive research is taking place. The company is in its early stage of development and is still in the process of defining its business model. It is located in Technological Park of Ljubljana.

Omega Ltd. was established in 1989. Since 1996 it represents two high-tech companies Perkin Elmer and Applied Biosystems from USA in Slovenia. Company's main mission is transfer and introduction of new, fast developing technologies and procedures from the fields of chemical analysis and molecular biology into Slovenian environment. Their field of work is chemical analysis, biochemistry, biology and physics. Very important company's mission is training of topmost professionals or researchers from the fields of activity. The company offers turnkey projects for known customers. Their main business partners are regional institutes for health care in Slovenia. Their business model is strongly connected to the parent companies in the USA on the fields of planning, organizing and reporting. The company is entirely independent on the fields of development and marketing their own products and services. It sells them in Slovenia and in countries of former Yugoslavia.

Genelitik Ltd. was established in 2008 by several individuals and relied highly on grant funding from the public enterprise fund. In 2011 a strategic investor provided additional capital for development. They develop processes in personalized genetics in the individual's feeding level—nutriogenomics. On the basis of DNA analysis they are able to prepare recommendations for altered feeding habits for individuals suffering from different diseases, weight problems etc.. Their vision is in five years to become a leading European bio-tech company in the field of diseases prevention measures and healthy way of life. For further financing of their research activity they are still quite dependant on EU budget research funding projects.

DiaGenomini Ltd. was established in 2010 by a group of young researchers in the field of biology and medical science and also co-financed by some corporate strategic investors. They employed three people at the time of interview and mainly deal with genetic analysis of intestines and breast cancer which would enable faster and more efficient cure treatment. They are expanding their research efforts in the field of cardio-vascular system which would eventually direct and individual to a healthier way of life. They also provide specialized trainings in order to provide some cash-flow for their daily operations.

IFB-Institute for Physical Biology Ltd. was established back in 2001 and employed 15 people at the time of interview. They are mostly dedicated into development of molecular and genomic tools for profiling, determination, quantification and, characterization of microbes associations. Their tools are applicable in the medical science, food industry, pharmaceutical industry and environment protection. Their business model is based on idea that once a service can be marketed it is spinned-off in another company.

\section{Results and Findings}

The responses given upon the research questions are outlined in Table 2. As described, the majority of the researched companies were established as private companies and do not share a public institution background. If we put them in the business life-cycle model they are in the range from mature companies to early-stagers or even 
start-ups. Their domain is mostly in life-sciences with a certain level of industrial application flair. Only one company can be regarded as a spin-off and even this spin-off was from another company because of the reason of a serious disagreement of founders regarding the strategy adoption and future business orientation.

Table 2

Synthesis of the Eight Cases

\begin{tabular}{|l|l|l|l|l|l|l|}
\hline Case & Founded & Spin-off & Patent & Initial organization & Domain & $\begin{array}{l}\text { Incubator/ } \\
\text { Tech-park }\end{array}$ \\
\hline C1 & 1990 & No & Yes & Private company & $\begin{array}{l}\text { solutions on the fields of tracking and monitoring } \\
\text { bioprocesses and simple LIMS }\end{array}$ & No \\
\hline C2 & $\begin{array}{l}1990 / \\
2004\end{array}$ & Yes & Yes & $\begin{array}{l}\text { Public non-for-profit study of electromagnetic fields impact on live } \\
\text { research organization }\end{array}$ & $\begin{array}{l}\text { No } \\
\text { organisms }\end{array}$ \\
\hline C3 & 1997 & No & Yes & Private company & $\begin{array}{l}\text { cell products intended to cure joint cartilage and } \\
\text { bone tissue }\end{array}$ & Yes \\
\hline C4 & 2005 & No & Yes & $\begin{array}{l}\text { Private company with } \\
\text { business angels' capital }\end{array}$ & personalized genetics & Yes \\
\hline C5 & $\begin{array}{l}1989 / \\
1996\end{array}$ & No & Yes & Private company & $\begin{array}{l}\text { chemical analysis, biochemistry, biology and } \\
\text { physics }\end{array}$ & No \\
\hline C6 & 2008 & No & No & Private company & personalized genetics-nutriogenomics & No \\
\hline C7 & 2010 & No & No & $\begin{array}{l}\text { Private company with } \\
\text { strategic investors }\end{array}$ & cell therapy-cancer & No \\
\hline C8 & 2001 & No & Yes & Private company & development of molecular and genomic tools & Nes \\
\hline
\end{tabular}

Note. Source: Own research, 2009.

As mentioned earlier, directors of Slovenian biotech companies were interviewed in our research. Following are results of these personal interviews, presented according to the questions.

RQ1: The origin of the idea and main source of motivation for entrepreneurship.

Speaking about age and professional experience, entrepreneurs in biotech companies show a wide span from such with 30 years of experience and 20 years of work in biotechnological company (BIA Co.) to very young entrepreneurs who have only finished their postgraduate studies and started their own business (Gene Planet) immediately. Postgraduate level of education is prevailing (master and doctoral degrees). All have extensive research experience on the fields of medical sciences, biotechnology, also chemistry and physics. Most of the younger ones originate from the "young researchers" government project. They established a biotechnological company either from the existential need, as they could not find appropriate job after finishing their studies and research work, either they have not found real challenges in large companies and research institutes, either they have established a company as a spin-off from bigger public research institutes. Some of them have joint biotechnological company upon invitation from these companies' founders and they have been previously successful on other fields of activities and technologies (e.g., IT technologies). Motives for entrepreneurial career were different, from implementation of their own vision from earlier days, to the motives arising from the existential need, to the spontaneous meetings and invitations for cooperation in biotechnological project.

RQ2: Decision to start a company on the field of biotechnology.

For most of our interviewees this has been a very logical and natural decision. They wanted to continue their careers in the field, which they studied in details and researched. Therefore a biotechnological company was a logical result of study and specialization, although they were perfectly aware that it is very difficult to establish and manage a successful biotechnological company. One of the companies (Omega) was established as a respond 
to the noticed opportunity and needs for representing a foreign company in Slovenia.

RQ3: Entrepreneurial background (family, relatives, acquaintances, friends, other).

Most of the answers were that they do not originate from families with entrepreneurial background and they have not considered entrepreneurship as a possible career path as they were interested mostly in the narrower field of biotechnology and in-depth study. The majority agree that there is probably no linkage between their personal decisions for study, research, entrepreneurship and environment in which they have grown up and study. Some of them come from families, where their parents were professors and researchers, but most of them come from families, where parents were public servants, belonging to generation in the former socialist system. The majority agree that "entrepreneurial genes” have not played a crucial role in a decision for entrepreneurial path on the field of biotechnology.

RQ4: Products and services.

The studied companies perform a wide range of activities. Educell grows cells in to cure and grow joint cartilage (cells for renewal of bone tissue for clinical use). Institute Bion studies the field of bio-fields or subtle fields and their impact on people, animals and plants. Results of their research are healing products. In perspective, this will become a new branch of pharmacy and pharmaceutical industry. Gene Planet offers personalized genetics services. It discovers inclination of someone to some chronic diseases and offers timely diagnostics of diseases that someone is exposed to. One of the companies is representing and selling products from American companies (Omega) and also sells instruments, materials and services on the fields of chromatography, biotechnology, organic synthesis and computer and laboratory equipment. The activities of the studied companies are very different from production, performance of proper research services, representation, sale, service and training.

RQ5: The business model (suppliers, customers, marketing strategy, business economics and control of costs, break-even point).

Several business models are revealed in the sample, from classical agency for a foreign partner, selling equipment from foreign suppliers to larger pharmaceutical companies, to production of biotechnological material (cells) and connection to one large customer, and to entirely entrepreneurial approach to development and marketing the service of personalized genetics. All the companies strictly control their costs and cooperate with more suppliers. They monitor and control costs of labor and fixed costs of operation. Most of our interviewees revealed that they have not reached the break-even point or that they have to fight for positive operations all the time. Marketing activities are performed on different ways apart from contemporary information technologies they prefer personal communication with customers.

RQ6: Opinion about biotechnological environment, status of biotechnology, possibilities of development in Slovenia and in wider region.

Most of interviewees agree that Slovenia is a too small country for realization of large biotechnological projects. Our neighboring countries (e.g., Austria) are biotechnologically well developed, but centers of knowledge and personnel in the region are dispersed and too competitive to each other to be able to achieve a critical mass for a biotech region. Big breakthroughs on the field of biotechnology in Europe and in the world can be done only by large companies and research laboratories, which invest big financial assets. The temporary politics is in Slovenia too reserved regarding support to smaller development centers, which should successfully 
develop also by the assistance of EU funds. Acquiring money from tenders of European Commission is very demanding and often too bureaucratic. In Slovenia legislation on the field of biotechnology is slowly being established. All interviewees expect higher level of connecting between biotechnological companies, research institutes or laboratories, a stronger political support and better organization in access to financial incentives from EU.

RQ7: Expectations from the support institutions on the field of entrepreneurship (ministries, universities, research institutes, governmental agencies, incubators, technological parks).

Most of interviewees only have modest expectations from the support environment. According to their opinion, too many of the state budget assets are spent unintentionally or, with a very small benefit in comparison with technologically successful countries. They agree that we need technology parks, incubators and tech-zones, which can offer legal, organizational, spatial and financial support to biotechnological companies. More spin-off companies from universities and research institutes could be started if administrative incentive mechanisms from the government would be more friendly (legislation, adequate financing). Financing priorities should be changed and criteria for competing at public tenders for research for smaller companies should be at least partly adjusted. Universities and research institutes have a good name, a good infrastructure and a high level of trust. But cooperation with biotechnological companies is on a very low level because since there seems to be no will and enthusiasm from some responsible individuals and researchers to cooperate.

\section{Conclusions and Implications}

This paper aimed at understanding the main features of entrepreneurship in biotech through a detailed analysis of the foundation of eight companies in Slovenia. Our objective was to go into the black box in order to analyze the genesis of new biotech ventures. Research questions raised here should hence provide a good starting point for more quantitative research that will confirm or invalidate them.

Our analysis enabled us to stress several characteristics of entrepreneurship in biotech. A first insight deals with the motivations that drive the founders, at least when they come from the academia. We have seen that those motivations are usually not directly based on money but on more complex mechanisms. Scientists may, for instance, want to foster the industrial exploitation of their research in order to make them benefit general public. Or they may wish to increase research budget and achieve more freedom for their research. More generally, scientists may want to join industry because it often offers more opportunities coming out from flexibility than the public sector (i.e., universities and research institutions). Yet, we have also seen that this willingness to create a venture in order to pursue his research also entails risks. Projects that are too far from the market usually do not survive very long. Also in our case, it would be a very difficult task to forecast how many companies will be successful. There is a certain impression that marketing imperative is still subordinated to the research/scientific ambitions of entrepreneurs which still tend to be their main vision for the future development of their careers.

Beyond the motivations of the founders, we emphasized three broad points that appear as central within the entrepreneurship process: The role of public science, the role of patents and the collective dimension of start-ups' creation. First, biotech entrepreneurship in Slovenia cannot be understood without public science. Most new biotech firms are founded by former public scientists, that, definitely, has some historic origins and almost all biotech start-ups acknowledge strong links with at least one public lab. Second, for biotech firms involved in drug 
production, patents are highly necessary. New ventures cannot exist without a strong patent system. Third, the process of entrepreneurship in biotech is a distributed process in the sense that it does not rely on one single entrepreneur but on the assemblage of a mix of competences distributed over a wide range of individuals and organizations.

To conclude, we believe that a promising approach of entrepreneurship in biotech deals with the notion of distributed entrepreneurship. Entrepreneurship in biotech is never the fact of one single player, neither is it the fact of several firms that just share knowledge or other items. Rather, entrepreneurship arises in a collective network of heterogeneous actors, each of them acting on a fraction of the system but being inseparable from the other members, implying that the whole is worth more than the sum of each of its parts. In this sense, although there may be a leader who directs the project, each player takes a role and it may be very damaging for the overall efficacy of the project to exclude some players.

It is believed that entrepreneurs without stabile market revenues can be still regarded as nascent entrepreneurs, no matter for how long they have been employed in their own company. Knowledge of factors that determine the transition from nascent entrepreneurship into real entrepreneurship is of major importance for policies aiming to effectively stimulate start-ups including bio-tech start-ups. However, scientist concentrated on person-specific factors to explain transition probabilities, environmental characteristics have been fairly neglected. Controlling for technology and individual characteristics, there is a significant impact of general regional opportunities, specific regional opportunities and the entrepreneurial environment for the probability of transition from nascent entrepreneurs to real start-ups.

\section{References}

Ahn, M. J., \& Meeks, M. (2008). Building a conductive environment for life science based entrepreneurship and industry clusters. Journal of Commercial Biotechnology, 14, 20-30.

Audretsch, D. B. (2001). The role of small firms in U.S. biotechnology clusters. Small Business Economics, 17, 3-15.

Baum J. A. C., Calabrese, T., \& Silverman, B. S. (2000). Don’t go it alone: Alliance network composition and start-ups' performance in Canadian biotechnology. Strategic Management Journal, 21(3), 263-294.

Becker, M. C. (2004). Organizational routines: A review of the literature. Industrial and Corporate Change, 13(4), 643-677.

Brown, J. T., \& Kant, A. C. (2009). Creating bioentrepreneurs: How graduate student organizations foster science entrepreneurship. Journal of Commercial Biotechnology, 15(2), 125-135.

Bureth, A., Levy, R., Pénin, J., \& Wolff, S. (2005). Strategic reasons for patenting: Between exclusion and coordination rationales. Rivista di Politica Economica, VII-VIII, 19-46.

Cohen, W. M., Nelson, R. R., \& Walsh, J. (2002). Links and impacts: The influence of public research on industrial R\&D. Management Science, 48(1), 1-23.

Combs, R. R., \& Metcalfe, J. S. (2002). Innovation in pharmaceuticals: Perspectives on the co-ordination, combination and creation of capabilities. Technology Analysis and Strategic Management, 14(3), 261-271.

Cooke, P. (2001). Biotechnology clusters in the U.K.. Small Business Economics, 17(1-2), 43-59.

DiMasi, J. A., Hansen, R. W., \& Grabowski, H. G. (2003). The price of innovation: New estimates of drug development costs. Journal of Health Economics, 22(2), 151-185.

Fuchs, G. (2001). Biotechnology in comparative perspective-Regional concentration and industry dynamics. Small Business Economics, 17(1-2), 1-22.

Hemphill, T. A. (2003). Preemptive patenting, human genomics, and the US biotechnology sector: Balancing intellectual property rights with societal welfare. Technology in Society, 25(3), 337-349.

Jolivet, E., Lanciano-Morandat, C., Nohara, H., \& Pardo, D. (2009). Biopharmaceutical entrepreneurship in two Japanese and French bioclusters: Differences in founder profiles and experience. Asian Business and Management, 8(4), 429-460.

Metcalfe, J. S. (2004). The entrepreneur and the style of modern economics. Journal of Evolutionary Economics, 14(2), 157-175. 
Nilsson, A. (2001). Biotechnology firms in Sweden. Small Business Economics, 17(1-2), 93-103.

Orsenigo, L. (2001). The (failed) development of a biotechnology cluster: The case of Lombardy. Small Business Economics, 17(1-2), 77-92.

Patzelt, H., \& Audretsch, D. B. (2008). The evolution of biotechnology in hostile financing environments. Journal of Organizational Change Management, 21(6), 773-785.

Prevezer, M. (2001). Ingredients in the early development of the U.S. biotechnology industry. Small Business Economics, 17(1-2), 17-29.

Radosevic, S. (2002). Regional innovation systems in central and eastern Europe: Determinants, organizers and alignments. The Journal of Technology Transfer, 27(1), 87-96.

Robbins Roth, C. (2001). From alchemy to IPO: The business of biotechnology. Boston: Perseus Books.

Stuart, T. E., \& Ding, W. W. (2006). When do scientists become entrepreneurs? To social structure antecedents of commercial activity in the academic life sciences. American Journal of Sociology, 112(1), 97-144.

Waltz, E. (2006). Commentary: School for the bilingual: Dual master's degrees in business and biotech. Journal of Business Chemistry, 3(2), 3-5.

Wolff, G. (2001). The biotech investor's Bible. London: John Wiley \& Sons.

Wolf, H., Michelsen, C., \& Schwartz, M. (2010). Regional entrepreneurial opportunities in the biotech industry: Exploring the transition from award-winning nascent entrepreneurs to real start-ups. Halle: Institute for Economic Research.

Zucker, L. G., \& Darby, M. R. (1999). Star scientists linkages to firms in APEC and European countries: Indicators of regional institutional differences affecting competitive advantage. International Journal of Biotechnology, 1(2), 119-131.

Zucker, L. G., Darby, M. R., \& Brewer, M. B. (1998). Intellectual human capital and the birth of US biotechnology enterprises. American Economic Review, 88(1), 290-306. 